\title{
SPOUSE'S COUNTER PRESSURE PRACTICE METHOD FOR REDUCING PAIN OF MOTHER'S IN FIRST STAGE LABOUR
}

\author{
(Praktik Metode Counter Pressure oleh Suami untuk Mengurangi Nyeri Ibu \\ dalam Proses Persalinan Kala I)
}

\author{
Sri Rejeki, Tri Hartiti, Nikmatul Khayati \\ Faculty of Nursing and Health Sciences \\ University of Muhammadiyah Semarang, 50248, Central of Java \\ E-mail: ii_rejeki@yahoo.com
}

\begin{abstract}
ABSTRAK
Pendahuluan. Nyeri hebat pada proses persalinan dapat menyebabkan ibu mengalami gangguan psikologis, $87 \%$ post partum blues pascapersalinan, 10\% depresi dan 3\% dengan psikosa. Salah satu metode untuk mengurangi nyeri persalinan adalah dengan melakukan Counter Pressure pada regio sakralis, namun aplikasi metode ini biasanya hanya dilakukan oleh tenaga kesehatan. Penelitian ini bertujuan untuk mengetahui gambaran praktik Counter-pressure yang dilakukan oleh suami untuk mengurangi rasa nyeri isteri dalam proses persalinan. Metode. Metode penelitian adalah descriptive analytic design. Sebagai populasi adalah para suami yang menunggu ibu dalam proses persalinan kala I yang telah dilatih metode Counter-pressure. Sebanyak 40 orang suami terpilih menjadi sampel yang diambil dengan Consequtive Sampling. Hasil. Hasil penelitian diperoleh praktik suami dalam tindakan Counter-pressure 75\% baik. Rasa nyeri isteri setelah dilakukan Counter- pressure oleh suami 60\% rasa nyeri berkurang. Diskusi. Penting menyertakan suami/pasangan dalam menurunkan tingkat nyeri ibu dalam proses persalinan.
\end{abstract}

Kata kunci: Metode Counter Pressure, nyeri persalinan, praktik suami

\section{ABSTRACT}

Introduction. Pain in childbirth cause the psychological disorders for mothers, such as $87 \%$ of postpartum blues, $10 \%$ of depression and 3\% of psychosis. One method to reduce the pain of childbirth is to give counter pressure on the sacral region, but the application of this method is usually only done by health workers. The purpose of this study was to describe the practice of counter-pressure made by the husband and wife to relieve pain in labour. Method. Research method used descriptive analytic design. As the population were 40 husbands who waiting for their wifes at first stage of labour. The husbands have been trained about counter-pressure methods. The sampling method used consecutive sampling method. Result. Obtained $75 \%$ husbands did well for practicing counter-pressure method, $60 \%$ women claimed reducing of pain after given counter- pressure by their husband. Discussion. This is importance to spouse presence in first stage labour for reducing the pain of mothers in childbirth.

Keywords: counter pressure method, pain of childbirth, the husband practices

\section{INTRODUCTION}

Most deliveries (90\%) are always accompanied by pain while in labor pain is a common thing to happen, the pain of labor is a physiological and psychological processes (Ministry of Health 2007). Reported from 2,700 women that giving birth only $15 \%$ of births take place with mild pain, 35\% with moderate pain, $30 \%$ with severe pain and $20 \%$ of deliveries with very severe pain (Niven \& Gijsbers, 1984).

Health statistics of Central Java (2003) obtained deliveries by skilled health personnel is not maximum $82.75 \%$, and in particular the county Kendal obtained $64.71 \%$ figure means that about $35 \%$ of deliveries are handled by other than medical personnel. Moreover likely deliveries take a patient's own home. Labor pain can stimulate the release of chemical mediators such as prostaglandins, leukotrienes, thromboxane, histamine, bradykinin, substance $\mathrm{P}$, and serotonin, will result in the secretion of stress hormones such as catecholamines cause and steroids with consequent vasoconstriction of the blood vessels to weaken intestinal contractions. Excessive secretion of these hormones will cause interference uteroplacental circulation resulting in fetal hypoxia. From the research, pain in childbirth causes women experience 
psychological disorders, $87 \%$ post partum blues that occur from 2 weeks to 1 year postpartum, $10 \%$ and $3 \%$ depression with psychosis (Perry \& Potter, 2006).

Labor pain is not unbearable encourage maternal looking for some alternatives to treat pain, including the use of pain medications such as analgesics and sedatives (Anita A, Ocviyanti D, SD \& Handaya Wisnuwardhani, 2002). While these drugs can give adverse side effects include fetal hypoxia, the risk of neonatal respiratory depression, decreased heart rate and increased maternal body temperature and may cause changes in the fetus (Mender \& Rosemary, 2003). There fore interventions reduce labor pain is very necessary in order to reduce complications in the mother and fetus during the process and after delivery. Non farmakologi intervention reduces pain, among others, hypnosis, acupressure, yoga, hydrotherapy, acupunctur, Counter Pressure breathing and relaxation techniques.

Counter Pressure sacral region proven to reduce labor pain but not much done. This method is relatively easy to do by the health worker and his family, especially her husband to help her reduce the level of labor pain. The importance of the role of the family, especially the husband in a decrease in the level of pain in labor should be recognized as an appropriate strategy, because here husband and can act as a psychological support to the wife in labor, so as to reduce morbidity and maternal mortality rates are not directly impact on reducing vulnerability and addressing the impact of the disease. This study aimed to describe how her husband practices after getting training methods Counter Pressure to reduce pain in first stage labor.

\section{METHODS}

This study used descriptive which gives an overview of the practice of husbands reduce maternal pain in the first stage of labor by using a counter-pressure. The populations of this study were all women giving birth by normal delivery at the first stage and as a whole, maternal sample was the normal delivery at the first stage of which is in the Kendal Hospital, with a sample that meets the criteria watchman husband and wife, the first wife. The sample was taken by using concequtive sampling.

The instrument in this study was a set of tools in the form of instruments action steps that are used to guide him into doing counter-presure, and set of tools for measuring instruments that have been validated pain respondent.

\section{RESULTS}

Table 1. Characteristic Behavior While Training on Counter Pressure on the Respondent (Husband) in Soewondo Hospitals, Kendal, 2014, N = 40

\begin{tabular}{clcccc}
\hline \multirow{2}{*}{ No } & \multicolumn{1}{c}{ Spous Behavior while training } & \multicolumn{2}{c}{ Do } & \multicolumn{2}{c}{ Not done } \\
\cline { 2 - 6 } & (n) & (f) & (n) & (f) \\
\hline 1 & $\begin{array}{l}\text { Husband listens to the goals Counter Pressure } \\
\text { Method }\end{array}$ & 26 & 60,0 & 14 & 40,0 \\
2 & $\begin{array}{l}\text { Husband listens to the way action reduces labor } \\
\text { pain with Counter Pressure }\end{array}$ & 36 & 90,0 & 4 & 10,0 \\
3 & $\begin{array}{l}\text { Active husband asked as an explanation } \\
4\end{array}$ & 20 & 50,0 & 20 & 50,0 \\
& $\begin{array}{l}\text { Husband can take action to correct the Counter } \\
\text { Pressure least 3 X while training }\end{array}$ & 32 & 80,0 & 8 & 20,0 \\
5 & $\begin{array}{l}\text { Husband willing to act counter pressure when } \\
\text { the wife felt pain in the first stage of labor }\end{array}$ & 40 & 100,0 & 0 & 0 \\
\hline
\end{tabular}


Table 2. Table Mean Value of The Husband's Behavior in The Training of Counter Pressure in Soewondo Hospitals, Kendal, 2014, N = 40

\begin{tabular}{lcc}
\hline \multicolumn{1}{c}{$\begin{array}{c}\text { Value Frequency Practice } \\
\text { Category }\end{array}$} & $\begin{array}{c}\text { Frequency } \\
\text { F }\end{array}$ & $\begin{array}{c}\text { Percentage } \\
\text { \% }\end{array}$ \\
\hline Both (Score 200-400) & 31 & 77,0 \\
Less well (Score $<200)$ & 9 & 23,0 \\
\hline Total & 40 & 100 \\
\hline
\end{tabular}

Table 3. Characteristics of Pain to Reduction Measures by Respondent (Spouse) to Counter Pressure Practice in Soewondo Hospitals Kendal, 2014, N = 40

\begin{tabular}{|c|c|c|c|c|c|}
\hline \multirow{2}{*}{ No } & \multirow[t]{2}{*}{ Counter pressure action } & \multicolumn{2}{|c|}{ Do } & \multicolumn{2}{|c|}{ Not done } \\
\hline & & (n) & (f) & (n) & (f) \\
\hline 1 & $\begin{array}{l}\text { Husband tells wife Pressure Counter measures to reduce } \\
\text { labor pain }\end{array}$ & 38 & 95,0 & 2 & 5,0 \\
\hline 2 & $\begin{array}{l}\text { Husband gives wife a position as comfortable as possible } \\
\text { on the felt labor pain }\end{array}$ & 20 & 50.0 & 20 & 50,0 \\
\hline 3 & $\begin{array}{l}\text { The husband gave the left lateral position before the action } \\
\text { of pressure Counter }\end{array}$ & 28 & 70,0 & 12 & 30,0 \\
\hline 4 & $\begin{array}{l}\text { Fourth husband looking for the right spot to apply pressure } \\
\text { with Counter Pressure to reduce the pain of his wife }\end{array}$ & 32 & 80,0 & 8 & 20,0 \\
\hline 5 & $\begin{array}{l}\text { Husband doing a strong push at the point in the lower back } \\
\text { (sacral REGIO) during contraction using the heel of the } \\
\text { hand }\end{array}$ & 36 & 90,0 & 4 & 10,0 \\
\hline 6 & $\begin{array}{l}\text { Husband doing a strong push at the point in the lower back } \\
\text { (sacral REGIO) during the contraction of the thumb }\end{array}$ & 24 & 60,0 & 16 & 40,0 \\
\hline 7 & $\begin{array}{l}\text { The husband asked his wife whether the pain is reduced } \\
\text { when performed counter-pressure }\end{array}$ & 36 & 90,0 & 4 & 10,0 \\
\hline 8 & $\begin{array}{l}\text { Husband always do a counter-pressure when the wife felt } \\
\text { pain during childbirth }\end{array}$ & 28 & 70,0 & 12 & 30,0 \\
\hline
\end{tabular}

Table 4. Mean Values Husband Practices in Conducting Counter Pressure to Counter Pressure Practice In Soewondo Hospitals Kendal, 2014, N = 40

\begin{tabular}{lcc}
\hline \multicolumn{1}{c}{ Value of practice } & $\begin{array}{c}\text { Frequency } \\
\text { F }\end{array}$ & $\begin{array}{c}\text { Percentage } \\
\mathbf{\%}\end{array}$ \\
\hline Both $($ Score $320-640)$ & 30 & 75,0 \\
Less well $($ Score $<320)$ & 10 & 25,0 \\
\hline Total & 40 & 100 \\
\hline
\end{tabular}

Table 5. The Frequency of Pain After Doing Counter Pressure By Husband in Soewondo Hospitals Kendal, 2014, $\mathrm{N}=40$

\begin{tabular}{lcc}
\hline \multicolumn{1}{c}{ Level of Pain } & Frequency & $\begin{array}{c}\text { Percentage } \\
\mathbf{\%}\end{array}$ \\
& F & 60 \\
Reduced & 24 & 27,5 \\
Not reduced & 11 & 12,5 \\
Increased & 5 & 100 \\
\hline Total & 40 & \\
\hline
\end{tabular}




\section{DISCUSSION}

According to Bobak (2005) factors that affect reproductive health support to her husband, that knowledge about pregnancy and childbirth, experience, marital status, and socioeconomic status. From the research data obtained $35 \%$ of elementary schooleducated husbands and $85 \%$ of workers are adah husband's job as a factory worker, shop workers and other workers. This suggests that the husband's education level and family income is low relatively low.

Husband's support is very important in the delivery process. Because at the time of delivery occurs physiologically severe pain interfere with the mother. From the results, the husband's behavior when trained counterpressure is $77 \%$ of this kind of behavior shows their husband's attention when obtaining information relating to the wife in the delivery process is very large. The behavior of a good husband provides convenience in receiving information in the training of counter-pressure. This is consistent with the findings that $80 \%$ of men can perform actions Counter-pressure 3 times correctly. The results of this study reinforced by research conducted Arif (2002) that there is a relationship role of the husband of the behavior of pregnant women in service delivery.

In general, from the results, the practice of the husband to perform counter-pressure is good (75\%) it shows no concern in giving support to the wife in labor. In the face of labor required consultation and support from family, especially her husband. Age is one indicator that can reflect the maturity of someone in the act, including in decisionmaking. The average age of the husband is 32 years old, it shows the average husband belonged to a young adult. Young adults can show positive behavior in preparing for the future, including in preparing a generation descendant of the family, especially the reproductive developmental tasks. Minimum age is 18 years old husband (7.5\%) of this age is still part of adolescence to early adulthood is possible still less mature in the decision included in the act of doing spousal support (included in the delivery process). From the research data obtained there is still $23 \%$ less good husband in training Counter pressure and $25 \%$ less well in practice counter-pressure. This is possible because the husband is still there under the age of 20 years.

Age also affects a person responds to pain. Judging from the average age of the respondent (wife) is 28 years showed a majority in the age group 20-30 years, in addition to the average of the respondents were in the productive age, as well as physiologically possible still withstand labor pain. However, in addition to individual pain response, pain is influenced by many things such as the environment, race, certain the actions and also the pattern of one's coping in the face of pain.

The result showed that $22 \%$ of mothers who received Counter-pressure measures were primigravida and has had second though, it means the mother has had previous experience of overcoming pain. The results of the study mothers pain after Counter-pressure is reduced pain by her husband as much as $60 \%$ of mothers and only a small proportion is $12.5 \%$ said the pain increased after the counter-pressure by the husband, and $27.5 \%$ of mothers say no change in pain even after counter-pressure by her husband. According Hutajulu (2003) individual labor pain and many other factors are very influential.

\section{CONCLUSIONS}

Counter pressure action performed by the spouse's can reduce pain of mother in first stage childbirth.

\section{RECOMMENDATIONS}

From these results it is suggested that health workers involving husbands birth attendants in the delivery process especially in reducing labor pain. 


\section{REFERENCES}

Anita A, Ocviyanti D, Wisnuwardhani SD, Handaya. 2002. Gambaran Intensitas nyeri pada persalinan menggunakan metode VAS dan VRS. MOGI. 2002; 26(4): hal 189-250.

Arif, Syamsul. 2002. Kesehatan reproduksi wanita, siapa peduli?. Majalah Suara Hidayatullah

Bobak, I.M., et al. Maternity Nursing. 2005. (Wijayanti, MA \& Anugrah, PI penerjemah). California: Mosby. (Sumber asli diterbitkan 1995).

Departemen Kesehatan Republik Indonesia. 2007. Survey Demografi Kesehatan Indonesia 2007.
Hutajulu. P. 2003. Pemberian Valetamat Bromida dibandingkan Hyoscine $N$ Butil Bromida untuk mengurangi nyeri persalinan. Bagian Obstetri Ginekologi USU.

Mender, Rosemary. 2003. Nyeri Persalinan. Jakarta: EGC.

Niven C, Gijsbers K. 1984. A study of labor pain using the McGill pain questionnaire. Soc Sci Med 1984; 19: 1347-51.

Potter. P, Ann Griffin Pery. 2006. Fundamental of Nursing; Concep Process And Prectice, 4th ed Missoury: Mosby Year Book Inc. St Louis. 